INSIGHTS INTO REGIONAL DEVELOPMENT

ISSN 2669-0195 (online) http://jssidoi.org/IRD/ 2019 Volume 1 Number 1 (March)

http://doi.org/10.9770/IRD.2019.1.1(3)

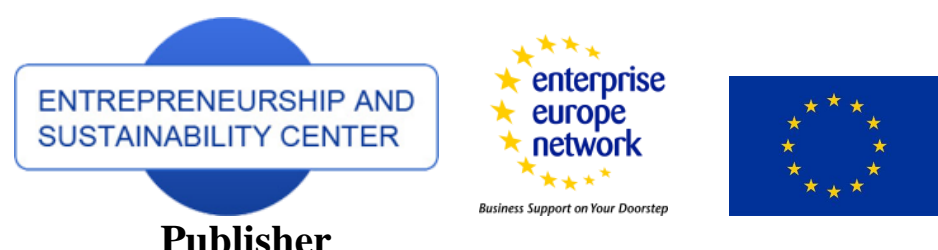

http://jssidoi.org/esc/home

\title{
THE IMPACT OF GLOBALIZATION ON REGIONAL DEVELOPMENT AND COMPETITIVENESS: CASES OF SELECTED REGIONS*
}

\author{
Zane Zeibote $^{1}$, Tatjana Volkova ${ }^{2}$, Kiril Todorov ${ }^{3}$ \\ University of Latvia, Raina Boulevard 19, Riga, LV-1586, Latvia \\ BA School of Business and Finance, K. Valdemara Street 161, Riga, LV-1013 \\ University of National and World Economy, 1, $8^{\text {th }}$ December Blvd., 1700 Sofia, Bulgaria \\ E-mails: ${ }^{1}$ Zane.zeibote@lu.lv; ${ }^{2}$ Tatjana.volkova@ba.lv; ${ }^{3}$ katodorov@unwe.bg
}

Received 18 November 2018; accepted 27 February 2019; published 30 March 2019

\begin{abstract}
The objective of this study is to conduct an analysis of regional development and competitiveness in the EU and Latvia under current conditions of economic globalization. This paper makes an attempt to evaluate a theory of regional development and regional competitiveness concept in relation to regional competitiveness in the light of current global economic changes. The authors emphasise that the regional development is based on competitive advantages, which has been a subject of fundamental research by Michal Porter and that serves as a basis for the current scientific methodology to assess competitiveness of regions and countries. The authors support a view of many scholars to consider regional competitiveness as the capacity of a region (or country) to create and support competitive economic environment. Further research reveals the impact of globalization on regional development by analysing interaction between the Globalization Index (GI) and the Global Competitiveness Index (GCI). Quantitative and qualitative analysis, i.e. literature analysis, comparative analysis and correlation analysis performed for this study reflect that competitiveness under global economic conditions is determined by the development stage of each region - competitiveness of a less developed region is more dependent on production factors, while competitiveness of a higher developed region is based on innovation. The correlation analysis reveals that the impact of globalization is stronger for those EU countries, which are in the efficiency-driven stage of development thank for those, which are in the innovationdriven stage. The results of this research could be useful for economic policy makers to determine the role of institutions, policy
\end{abstract}

\footnotetext{
* The research leading to these results has received funding from the European Union Seventh Framework Programme (FP7
} 2007-2013) under grant agreement No. 291823 Marie Curie FP7-PEOPLE-2011-COFUND
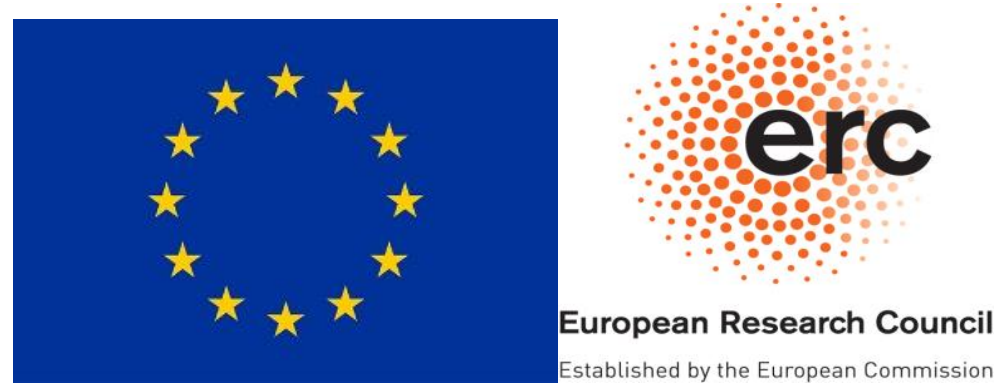


\section{INSIGHTS INTO REGIONAL DEVELOPMENT}

ISSN 2669-0195 (online) http://jssidoi.org/jesi/

2019 Volume 1 Number 1 (March)

http://doi.org/10.9770/IRD.2019.1.1(3)

instruments and factors, which are necessary for attaining higher productivity, efficiency and profitability better withstand forces of competition on global and regional markets.

Keywords: regional development; competitiveness; globalisation; impact; the EU, Latvia

Reference to this paper should be made as follows: Zeibote, Z. 2019. The impact of globalization on regional development and competitiveness: cases of selected regions, Insights into Regional Development 1(1): 33-47. http://doi.org/10.9770/IRD.2019.1.1(3)

JEL Classifications: R10, R11

\section{Introduction}

The concept of regional economy was developing parallel to evolvement of the regional development theory, which led to acknowledging the importance of cities and regions or territories. In the light of a debt crisis of late 1980ies and early 1990ies, as well as increasing globalization, the success factors behind achieving the economic development became even more significant and led to applying new approaches for attracting resources necessary for the development, such as turning regional comparative advantages into competitive advantages resulting in a new development stage of a territory - competitiveness.

Therefore, this paper is focusing on the analysis of competitiveness of state (territory), not business or market competitiveness. For analysing the factors of competitiveness this paper evaluates main sources of competitiveness according to M. Porter's Diamond Model, two the most important competitiveness researches World Competitiveness Yearbook and Global Competitiveness Report. The global competitiveness ratings based of the Global Competitiveness Report (2015) and globalisation index ratings based on the KOF Globalization Index (2015) have been considered as an empirical basis to measure the impact of globalization on regional competitiveness and used for the quantitative analysis of this research.

In the framework globalization is viewed according to Amit K. Bhandari and Almas Heshmati (2005), who argue that the elements of globalization include free movement of goods and services, flow of capital, movement of labor and the transfer of technology which has brought the developed economies closer together and made them more strongly integrated. Although economic interconnectedness is the prime mover of globalization, the conflicting behaviour of environment, culture, political and social development antecedes contemporary development process. Apart from that globalization also indicates the flow of ideas, norms, informations and peoples.

According to the KOF Globalization Index the world's globalization has been contactly increasing since 1970ies and its growth trends have particularly increased after 1990ies (Please, see Figure 1). The globalization and its expansion have determined that today's regional stakeholders are forced to be competitive not only on a regional, but also on a global scale. 


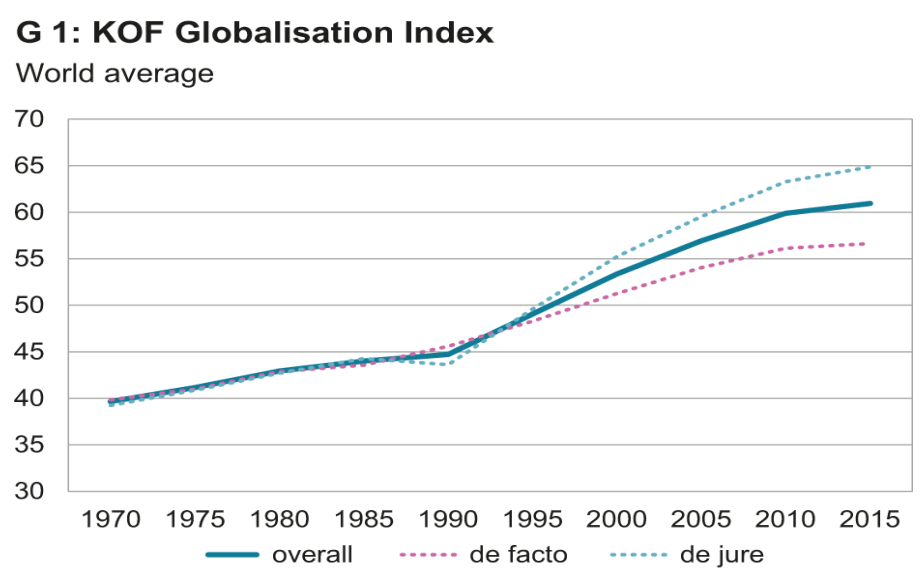

Figure 1. KOF Globalisation Index 1970 - 2015

Source: https://www.kof.ethz.ch/en/news-and-events/media/press-releases/2018/01/kof-globalisation-index-globalisation-down-worldwidein-2015.html

The research results reveal that the impact of globalization on the regional development depends on the development stage of the region in question. The competitiveness, which is based on productivity, efficiency and profitability presents capacity of a state or a region to produce export goods and services under of a market economy conditions, which successfully compete on the international market and is able to develop further during the transition to the next development stage. Those regions, which are on a higher development stage of innovation are also more competitive globally and can easier withstand forces of globalization.

\section{Concepts of Regional Economy and Development}

Until the second half of 20th century the dominating was economic development concept described by such prominent economists as Adam Smith (Smith A, 1776), David Ricardo (Ricardo D, 1817), John Stuart Mill (Mill J.S, 1859) and others. This economic development concept noted that the success of state and its socioeconomic model is based on high economic growth rates and productivity, as well as greater GDP and GDP per capita. This concept was used to explain the development of any territory. During 1940ies with evolving of the development economics, which were mainly focusing on accumulation of material wealth of countries, the leading theory was based on the Kein's macroeconomic model. The main shortage of the Kein's theory is the emphasis on money and material capital, however, doesn't recognize the importance of a human capital. This was considered that the economic growth automatically leads to the development of territories and their inhabitants, and that increase in the industrial production helps to reduce poverty and increases the overall wealth of people. The relationship between increase in production and reduction of poverty was considered so significant that the economic growth became the target indicator for development and was used as a basis for conducting economic policy.

Main principles of a modern regional development theory are based on aspects of the Shumpeter's regional development theory. However, it has developed over time and become much more complex requiring more integrated analytical approach. Evolving of the regional development theory was impacted by endogenous factors or the endogenous growth theory also called the New Growth Theory, which in addition to development factors of neoclassical economic theory - capital and labour, adds the third factor - knowledge. According to this theory the economic development results from investing in knowledge, which determined technological development possibilities of each region that correspond to particular environment, human resources and their use, as well as results achieved by new ideas, technologies and efficient management of resources (Audretsch D, Dohse D, 


\section{INSIGHTS INTO REGIONAL DEVELOPMENT}

ISSN 2669-0195 (online) http://jssidoi.org/jesi/

2019 Volume 1 Number 1 (March)

http://doi.org/10.9770/IRD.2019.1.1(3)

2007). This theory also recognizes the importance of external support for SMEs development, as well as stimulation of investment and development for promoting the growth of a country or a region.

Parallel to the regional development theory, also the regional economy concept was developed. Its advancement started during 1950ies in the U.S. and obtained a status of study discipline during 1990ies. The regional economy is a discipline, which focuses on objective preconditions for the regional economic development, production structures, social sphere and living conditions, economic management and its mechanisms, etc. (geographic location, natural resources, demography, potential for industrial production), as well as economic relations with other regions and countries. Regional economy is a sub-discipline of the regional science, which focuses on those economic aspects, which are related to territorial space and it is a territorial development economy by its nature (Экономическая библиотека, 2011).

During 1980ies and in the beginning of 1990ies the global debt crisis shifted the emphasis from the United Nations (UN) to the Bretonwood's institutions, such as the World Bank and the International Monetary Fund, which had "one approach for all" policy. This changed previous development priorities to qualitatively new approaches: reduction of state debt and expenditure, stopping economic recession, etc. In result, the UN's first annual Human Development Report (Mahbub ul Haq, 1991) became a starting point for recognizing a new branch of the science of economy - the development economy.

The success of a local economy or regional development is determined by the system of socio economic and cultural components: capacity of entrepreneurship; local production factors (capital and labour); mutual relations between local actors, which facilitate the absorption of cumulative knowledge; ability to take decisions, which permit local social and economic actors to lead development processes, provide support for their transformation and innovation, as well as enrich them with external information and knowledge, which is necessary to relate the development process to the overall development process and global economic, social, technological and cultural transformation (Capello, R., Caragliu, A., Nijkamp, P., 2009; Pietrzak, MB., Balcerzak, AP.; Gajdos,, A., Arendt, Ł, 2017; Sagiyeva, R,, Zhuparova, A., Ruzanov, R., Doszhan, R., Askerov, A., 2018; Lavrinenko, O. Ignatjeva, S. Ohotina, A. Rybalkin, O. Lazdans, D., 2019).

The European Union (EU) policy and planning documentation started to focus more on the role of cities and regions for territorial cooperation and differences around 2004 - 2005 (Commision of the European Communities, 2007), when the role of cities as main engines for the regional development, which should attract inhabitants and tourists under conditions of globalizations became more evident. This placed even more emphasis on such qualitative features of territories as cultural life, access to communal services and efficient institutions (Commision of the European Communities, 2005). Therefore, the impact of such non-economic factors as quality of live and attractiveness of environment became recognized as important territorial advantages. The sixth Progress Report of the EU on the Economic and Social Cohesion (Commision of the European Communities, 2009) includes theory of the researcher R. Florida, which defines three main factors for the economic and regional development, so called 3Ts - Technology, Talent and Tolerance (Florida R, 2011). According to R. Florida, if enterprise or city or region or territory has 3Ts then they are able to attract creative labour force, which can create innovation and promote economic development.

\section{Regional Competitiveness and Competitive Advantages}

The science of economy puts an emphasis on the analysis of factors, which facilitate the economic development, competitiveness and attractiveness of a territory. One of important territorial development factors is advantage of one territory against another, which helps to attract resources for the development. When a territory increases its attractiveness then comparative advantages turn into competitive advantages leading to a new development stage of a territory - competitiveness. The achievement of the competitiveness stage helps to ensure further efficient 


\section{INSIGHTS INTO REGIONAL DEVELOPMENT}

ISSN 2669-0195 (online) http://jssidoi.org/jesi/

2019 Volume 1 Number 1 (March)

http://doi.org/10.9770/IRD.2019.1.1(3)

and profitable use of attracted competitive resources, which ensures economic efficiency and improvement of economic indicators.

There are several differences between territorial competitiveness and advantages: the competitiveness is related to efficient and optimal use of resources, while the attractiveness means the ability to attract, keep and sustain resources on a particular territory. The competitiveness is more oriented to acknowledgement of development perspectives, while the advantages are focused on efficient and open business perspectives (Pellegrini G, 2006). The main difference between competitiveness and advantage is hidden in the level of active participation of the government in economy. The factors of attractiveness are based on the level of government support and they are almost fully under the influence and control of the government. At the same time, the factors of competitiveness are outside of the direct government influence (Serrano A, 2003).

Historically, the concept of competitiveness is related to the concept of competition, which developed during the era of capitalism. If the competition is a special type of economic environment, then the competitiveness is an ability of an economic subject to survive in this environment. Since 1980ies the competitiveness theory has become a new sub-sector of the theory of economy, which researches factors influencing the competitiveness of states and regions and is especially useful for analysing new economic globalization processes (Garelli S, 2002).

The World Economic Forum in its Global Competitiveness Report (GCR) defines the competitiveness as a combination of institutions, policies and factors, which determine productivity level of a territory. In addition, the productivity level determines the level of welfare, which can be achieved by an economy. Also, the productivity level determines the impact of a return of resources invested in the economy; and is the main engine for its development. Clearly, the economy, which achieves faster growth is more competitive. Therefore, the concept of competitiveness includes dynamic and static components: despite a fact that the productivity of a state determines its ability to sustain high source of income, the competitiveness is one of the most important factors for receiving profit from investment, which is one on the main indicators of the economic development (Schwab K, 2012). The GCR was first launched in 1980. In 2017 the GCR has analysed competitiveness of 137 world's countries.

The World Competitiveness Centre in its World Competitiveness Yearbook (WCY) of the International Institute for Management Development defines the competitiveness concept as an area of economic knowledge, which analyses facts and policies behind the ability of state to create and sustain the environment, which promotes the creation of higher value added for its enterprises and higher welfare level for its inhabitants. In other words, the competitiveness is how the nation manages its own and attracted resources to improve the welfare of its people (Garelli S, 2012). The WCY is being published since 1989 and in 2017 it included 63 countries, as well as for the first time - several regions, which were analysed on the same level as countries.

This is important to mention that on the European level (EU27) the EU Regional Competitiveness Index (RCI) has been built according to approach of the Global Competitiveness Index (WEF). This is the first composite indicator which measures territorial competitiveness of 27 EU Member States on NUTS 2 level. The RCI consists of eleven pillars grouped in three groups: 1) Basic, 2) Efficiency and 3) Innovation, which measure issues relevant to firms, as well as to residents of the regions and their quality of life. The Basic group includes five pillars: Institutions; Macroeconomic Stability; Infrastructure; Health; and Basic Education. The Efficiency group includes three pillars: Higher Education, Training and Lifelong Learning; Labour Market Efficiency; and Market Size. And the Innovation group consists of three pillars: Technological Readiness; Business Sophistication; and Innovation (European Commission, 2017).

The first edition of the RCI was published in 2011 followed by 2013 and 2016 editions. The 2016 RCI is based on 74 mostly regional indicators covering the 2012-2014 period, but with a number of indicators also from 2015 and 2016. The RCI definition of the competitiveness is quite simple: Regional competitiveness is the ability of a 


\section{INSIGHTS INTO REGIONAL DEVELOPMENT}

ISSN 2669-0195 (online) http://jssidoi.org/jesi/

2019 Volume 1 Number 1 (March)

http://doi.org/10.9770/IRD.2019.1.1(3)

region to offer an attractive and sustainable environment for firms and residents to live and work (European Commission, 2017). Therefore, the RCI is quite unique policy tool for monitoring and assessing the regional competitiveness in the EU. However, approaches used by the GCR and WCY are more useful, when looking on the impacts of globalization on regional economies.

The KOF Swiss Economic Institute Globalization Index (GI) measures the economic, social and political dimensions of globalisation. The GI is used in order to monitor changes in the level of globalisation of different countries over extended periods of time. The KOF Globalisation Index in for 2015 was available for 185 countries. The Index measures globalisation on a scale of 1 to 100. The methodology of calculating the KOF GI has changed over time. For example, instead of the previous 23 different variables, a total of 42 were included in calculating the GI for 2015. According to the literature review the KOF GI is the one of the first of its kind and unigue in terms of providing insight into globalization research.

The World Competitiveness Yearbook analyses several types of economic competitiveness by calculating various indexes: Global Competitiveness Index, GlCI; Growth Competitiveness Index, GCI; Business Competitiveness Index, BCI, Digital Competitiveness Ranking (since 2017). Therefore, a structure of the regional competitiveness can be quite easily determined, however, it is constantly changing, especially with the development of modern technologies. At the same time, this is quite difficult to evaluate operationalisation of the competitiveness factors. The scientific literature identifies different factors of regional competitiveness and there are also various classifications of those factors. Therefore, this is important to evaluate existing competitiveness ratings. According to Professor Michael Porter there are four main determinants, which serve as a basis of regional competitive advantages or environment, which is created and sustained by each region (Porter M, 1990):

- Production factors - determine the position of the region in relation to such production factors as qualified labour force and infrastructure, which is necessary to stand against forces of competition in a particular sector;

- Demand factors of regional market are related to products and services of a particular sector;

- Related and supportive industries - competitive sectors (enterprises) on a global market and presence of suppliers or related industries in the region;

- Strategy, structure and competition - regional conditions for the emergence of stakeholders, stakeholders' organizations and management, as well as internal competition.

The above mentioned factors determine the creation of a business environment for regional stakeholders. Each of these determinants is typical for a particular region and their combination provides important preconditions for global competitiveness of regional enterprises. The competitiveness and competitive advantages are important concepts for the economic development and growth, because they are firmly tied with the strategies and management of cities and regions (territories) for improving their inhabitants' welfare (Anderson R, 1999).

\section{Forces and factors behind regional economic development and competitiveness}

The economic globalization forces regional stakeholders to be competitive not only on a regional, but also on a global scale. This is the main condition of the globalization process, which impacts regional competitiveness and also influences economic thought and theory. Every region must be as competitive as possible to promote international competitiveness of its stakeholders and encourage their activity in a particular region or/and on a global market place. Professor Michael Porter was the first, who created the system of factors influencing the regional competitiveness, which is called the Diamond Model. The Diamond Model identifies the four forces of competitiveness based on the above mentioned four determinants: 1) Production factor (volume, quality and specialization of production factors); 2) Demand factor (experienced and demanding local consumer; requirements of consumers; untypical local demand in specific segments); 3) Structure and competition (local 


\section{INSIGHTS INTO REGIONAL DEVELOPMENT}

ISSN 2669-0195 (online) http://jssidoi.org/jesi/

2019 Volume 1 Number 1 (March)

http://doi.org/10.9770/IRD.2019.1.1(3)

situation, which support investment and continuous development; strong competition between local enterprises); 4) Related and supporting industries (presence of competitive local suppliers and competitive local industries).

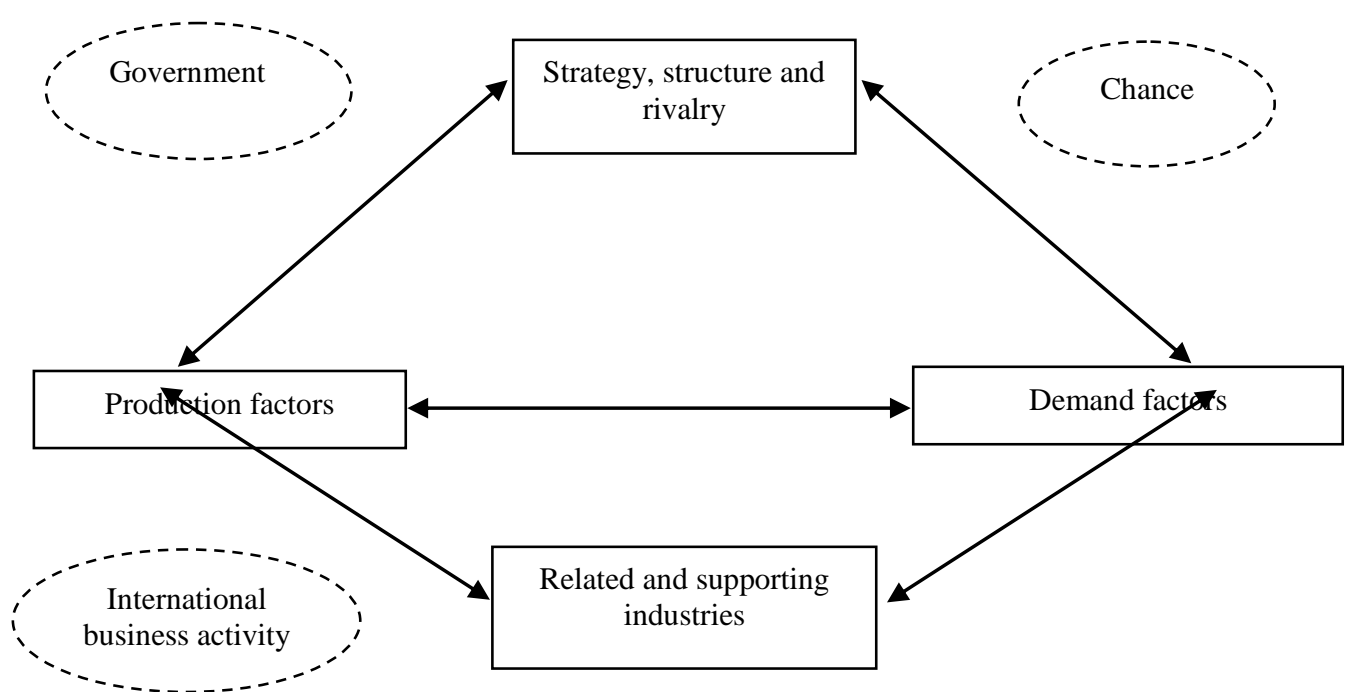

Figure 2. M. Porter's Diamond Model - regional competitiveness sources

Source: Hernesniemi H., Lammi M., Yla-Anttila P., 1996. Advantage Finland - The Future of Finnish Industries: ETLA [the Research Institute of the Finnish Economy] report of the Finnish clusters' study. Helsinki: Taloustieto Oy.

The Figure 2 shows the classical Diamond Model of Michael Porter (Porter M.E, 1998) amended with three newly added components important for the creation of a favourable business environment. These three new features were added by the Finnish researchers in their fundamental industrial research ,Advantage Finland - The Future of Finnish Industries" (Hernesniemi H., Lammi M., Yla-Anttila P, 1996) and include: 1) Government; 2) Chance; and 3) International business activity.

The government has an important role in several aspects, such as: 1) providing guaranty for sufficient supply of resources, which are necessary for the development, especially, factors for creating advantages; 2) creating basis for the economic development and innovation - measures for protecting environment, safety standards etc.; 3) ensuring functioning of the market system; and 4) stimulating the development of human capital.

The factor of chance has an important role in many industrial undertakings. For example, the Finnish researchers describe a case, where Mr. Lauri Rapala in 1936 established an enterprise for producing fishing equipment, which was rapidly expanding. However, the biggest success of this enterprise came by a chance, when Mr. Rapala appeared in the same "Life" magazine edition of 1962, which wrote about the death of Merilin Monroe. It was the most popular volume of the "Life" journal ever and it also helped to increase the image and popularity of Mr. Lauri Rapala and his business.

The International business activity was added to the Diamond model later in a result of discussion with J. Dunning (Dunning J, 1993). According to M. Porter's views multinational economic subjects are external elements with respect to the Diamond Model. He also considers that global economic subjects aren't meaningful in the presence of already established competitive advantages, because, there are such global economic subjects with their own corporative culture, which doesn't influence separate nations. 


\section{INSIGHTS INTO REGIONAL DEVELOPMENT}

ISSN 2669-0195 (online) http://jssidoi.org/jesi/

2019 Volume 1 Number 1 (March)

http://doi.org/10.9770/IRD.2019.1.1(3)

The stage of development of regions should be taken into account, when conducting the analysis of competitiveness and applying the Diamond Model. There are different factors influencing regional competitiveness in different stages of the development - each characterised by different forces. This aspect has been deeply researched by the GCR, which separate all regions under five categories corresponding to the three main development stages and two transition period stages.

The WEF has chosen the GDP per capita for the criteria for dividing regions into stages of economic development by defining precise limits of this indicator for each of the stages (Sala-i-Martin X. \& al, 2016) (Please, see Table 1).

Table 1. Development stages of regions and their forces, USD

\begin{tabular}{|c|c|c|c|}
\hline No. & Regional development stages & Main forces & GDP per capita \\
\hline 1. & Factor-driven-stage & Intensive use of production factors & 2000-2999 USD \\
\hline 2. & $\begin{array}{c}\text { Transition stage from factor to } \\
\text { efficiency driven stage }\end{array}$ & & $3000-8999$ USD \\
\hline 3. & Efficiency-driven-stage & $\begin{array}{c}\text { Productivity of resources used in the } \\
\text { economic activity }\end{array}$ & $9000-17000$ USD \\
\hline 4. & $\begin{array}{c}\text { Transition from efficiency to } \\
\text { innovation driven stage }\end{array}$ & Innovation & $<1700$ USD \\
\hline 5. & Innovation-driven-stage &
\end{tabular}

Source: authors' calculations according to Schwab K. (Ed.) (2014) The Global Competitiveness Report 2014-2015. Geneva: World Economic Forum; Schwab K. (Ed.) (2015) The Global Competitiveness Report 2015-2016. Geneva: World Economic Forum; Schwab K. (Ed.) (2016) The Global Competitiveness Report 2016-2017. Geneva: World Economic Forum.

Choice of the GDP per capita as the main criteria for dividing regions in the development stages is based on the assumption that production factors are determined by prices. The lowest prices are related to the lowest level of income and, therefore, the regions, where the GDP per capita is lower than USD 2000 belong to the first - Factor driven stage. The same reasoning is behind dividing regions, which are in the Transition from production to efficiency driven stage from regions in the Efficiency driven stage: the GDP per capita increases, because of increase in productivity and salary, which rises simultaneously with the region moving to the highest development stage, which requires to increase the productivity by applying much more complicated factors (Lopez-Claros A., Blanke J., Drzeniek M., Mia I., Zahidi S, 2006). As reflected in Table 2 the lowest numbers of the Global competitiveness indice average ranking correspond to the highest position of a country in the competitiveness rating.

Table 2. Average rank of the Global competitiveness index of countries in different stages of development

\begin{tabular}{|c|c|c|c|}
\hline Regional development & \multicolumn{3}{|c|}{ Global competitiveness indice average ranking } \\
\cline { 2 - 4 } stages & $\mathbf{2 0 1 4}$ & $\mathbf{2 0 1 5}$ & $\mathbf{2 0 1 6}$ \\
\hline Factor-driven-stage & 91 & 97 & 102 \\
\hline $\begin{array}{c}\text { Transition stage from factor } \\
\text { to efficiency driven stage }\end{array}$ & 72 & 72 & 68 \\
\hline Efficiency-driven-stage & 53 & 59 & 66 \\
\hline $\begin{array}{c}\text { Transition from efficiency to } \\
\text { innovation driven stage }\end{array}$ & 35 & 35 & 44 \\
\hline Innovation-driven-stage & 19 & 20 & 21 \\
\hline
\end{tabular}

Source: authors' calculations according to Schwab K. (Ed.) (2014) The Global Competitiveness Report 2014-2015. Geneva: World Economic Forum; Schwab K. (Ed.) (2015) The Global Competitiveness Report 2015-2016. Geneva: World Economic Forum; Schwab K. (Ed.) (2016) The Global Competitiveness Report 2016-2017. Geneva: World Economic Forum.

Components of sub-indexes of the GCI are determined according to the above mentioned regional classification methodology and correspond to the three forces (production, efficiency, innovation), which determine the three 


\section{INSIGHTS INTO REGIONAL DEVELOPMENT}

ISSN 2669-0195 (online) http://jssidoi.org/jesi/

2019 Volume 1 Number 1 (March)

http://doi.org/10.9770/IRD.2019.1.1(3)

aforementioned main stages of the regional competitiveness (Schwab K, 2015): 1) sub-index measuring basic factors (institutions; infrastructure; macroeconomic environment; health care and basic education); 2) sub-index measuring efficiency (higher education and training; goods market efficiency; labour market efficiency; development of financial market; technological readiness; market size); 3) sub-index measuring innovation and specialised factors (business attractiveness; innovation).

Latvia according to the GCI 2017-2018 ranks 54 ${ }^{\text {th }}$ among 137 world's countries, but in GCI 2016-2017 - $49^{\text {th }}$ among 138 world's countries, which means that according to Tables 1 and 2 Latvia with it's GDP of EUR 1154.33 or USD 1428.83 (Exchange rate set by the European Central Bank $=1.237800$ ) is in the Transition from production to efficiency driven stage. According to the GCR 2017-2018 the main drawbacks for Latvia are related to market size, institutions, infrastructure, innovation and business sophistication. Clearly, nothing much can be done about the market size since Latvia is a small country. However, other factors can be improved through applying right policy instruments. For example, innovation pillar ranking $83^{\text {rd }}$ among 137 countries includes following factors: Capacity for innovation ranking 57 $7^{\text {th }}$ among 137 countries; Quality of scientific research institutions ranking $51^{\text {st }}$ among 137 countries; Company spending on R\&D ranking $73^{\text {rd }}$ among 137 countries; University-industry cooperation on R\&D ranking $100^{\text {th }}$ among 137 countries; Government procurement of advanced technology products ranking $119^{\text {th }}$ among 137 countries; Availability of scientists and engineers ranking $109^{\text {th }}$ among 137 countries; PCT patents ranking $35^{\text {th }}$ among 137 countries. Moreover, the GCR names the most problematic factors for doing business in Latvia based on the opinion of executives, where the main three are: 1) Inefficient government bureaucracy; 2) Tax rates; 3) Tax regulations (Schwab K., 2017). Therefore, the GCR clearly identifies which areas are the most problematic ones and should be targeted first.

Components of the GCI are related to the regional development stages determining the weight of each sub-index depending on the regional competitiveness stage. Besides, when calculating the GCI value, each sub-index is determined according to the competitiveness stage of a particular region. A percentage of the main competitiveness factors - i.e. components of the GCI related to the main development stages of regions are shown in Table 3.

Table 3. The significance of main competitiveness factors according to development stages, $\%$

\begin{tabular}{|c|c|c|c|}
\hline \multirow{2}{*}{ Regional development stages } & \multicolumn{3}{|c|}{ Main competitiveness factors } \\
\cline { 2 - 4 } & Basic factors & $\begin{array}{c}\text { Promoters of } \\
\text { efficiency }\end{array}$ & $\begin{array}{c}\text { Inovation and } \\
\text { specialization factors }\end{array}$ \\
\hline Factor-driven-stage & 60 & 35 & 5 \\
\hline $\begin{array}{c}\text { Transition stage from factor to } \\
\text { efficiency driven stage }\end{array}$ & $40-60$ & $35-50$ & $5-10$ \\
\hline Efficiency-driven-stage & 40 & 50 & 10 \\
\hline $\begin{array}{c}\text { Transition from efficiency to } \\
\text { innovation driven stage }\end{array}$ & $20-40$ & 50 & $10-30$ \\
\hline Innovation-driven-stage & 20 & 50 & 30 \\
\hline
\end{tabular}

Source: Sala-i-Martín X., Baller S., Crotti R., Di Battista A., Drzeniek Hanouz M., Geiger T., Gómez Gaviria D., Marti G. (2016) Competitiveness agendas to reignite growth: Findings from the Global Competitiveness Index. In: Schwab K. (Ed.) The Global Competitiveness Report 2016-2017. Geneva: World Economic Forum, pp. 3-50.

Table 3 shows that the most important for increasing competitiveness of regions, which are on the lowest Production stage are basic factors (60\%) followed by factors for efficiency promotion (35\%) and only 5\% are allocated for innovation and specialized factors. At the same time, for regions, which are on the innovation stage the basic factors $(20 \%)$ and factors for efficiency promotion $(50 \%)$ are still quite significant, while the significance of innovation and specialization factors is much higher - 30\%, meaning that in the highest stage of competitiveness the innovation and specialized factors have the biggest impact on the regional competitiveness. 
INSIGHTS INTO REGIONAL DEVELOPMENT

ISSN 2669-0195 (online) http://jssidoi.org/jesi/

2019 Volume 1 Number 1 (March)

http://doi.org/10.9770/IRD.2019.1.1(3)

Countries or regions, which are in the Transition process have different composition of competitiveness factors depending on those, which have become more important for the development.

\section{The impact of globalization on regional devlopment and competitiveness}

For measuring the impact of globalization on regional development and competitiveness the Correlation between Globalization Index (GI) and Clobal Competitiveness Index (GCI) has been performed using the sample of 132 world countries. The calculation of the Srearman's rank correlation coefficient reveals that there is statistically significant $(\mathrm{p}=0,000)$ strong positive $(\mathrm{r}=+0,808) 2$-tailed correlation between GI and GCI within the whole sample of 132 world's countries (see Table 4). It means that countries with a higher level of globalization are more competitive and countries with higher level of competitiveness appear to be more globalized.

Table 4. Correlation between ranks of GI and GCI, Spearman's correlation coefficient, n-132 countries, 2015 Correlations

\begin{tabular}{|ccc|c|c|}
\hline & & & gi_rank & gci_rank \\
\hline & \multirow{3}{*}{ gi_rank } & Correlation Coefficient & 1,000 &, $808^{* *}$ \\
& & Sig. (2-tailed) & $\cdot$ &, 000 \\
& & $\mathrm{~N}$ & 132 & 132 \\
& \multirow{2}{*}{ gci_rank } & Correlation Coefficient &, $808^{* *}$ & 1,000 \\
& & Sig. (2-tailed) &, 000 & $\cdot$ \\
& & $\mathrm{N}$ & 132 & 132 \\
\hline
\end{tabular}

**. Correlation is significant at the 0.01 level (2-tailed).

Source: authors' own calculations using GI and GCI data

The correlation analysis between Globalization Index (GI) and Global Competitiveness Index (GCI) performed for different stages of development shows that the level of development of a country influences the correlation results.

While there are not any statistically significant results of correlation between globalization and competitiveness on transition stages of development, the three main stages of development: factor-drive; efficiency-driven and innovation-driven, have statistically significant correlation results. The efficiency-driven stage of development has the highest indicator of the GI and GCI correlation. (see Table 5). A considerable mathematical difference between general $r$ (see Table 4) and $r$ on the stages of development (see Table 5) could be explained with the fact that general correlation analysis was done within a larger sample $(n=132)$, while for a smaller sample (for development stage analysis) requirements for correlation coefficient were higher, because of a smaller number of a sample's units (countries).

Nevertheless, the highest correlation results for the efficiency-driven stage can be explained with the fact that globalization is more important for the competitiveness of a country on the efficiency-driven stage of development, which is a bases for futher increase in productivity. 
INSIGHTS INTO REGIONAL DEVELOPMENT

ISSN 2669-0195 (online) http://jssidoi.org/jesi/

2019 Volume 1 Number 1 (March)

http://doi.org/10.9770/IRD.2019.1.1(3)

Table 5. Correlation between ranks of GI and GCI on different stages of development of countries, Spearman's correlation coefficient, $n$ 132,2015

\begin{tabular}{|l|l|l|l|}
\hline $\begin{array}{l}\text { Stage of development of } \\
\text { countries }\end{array}$ & $\begin{array}{l}\text { Spearman's correlation } \\
\text { coefficient, } \mathbf{r}\end{array}$ & $\begin{array}{l}\text { Statistical significance*, } \\
\mathbf{p}\end{array}$ & $\begin{array}{l}\text { Number of } \\
\text { countries }\end{array}$ \\
\hline Factor-driven stage & $\mathbf{+ 0 , 3 7 9}$ & 0,036 & 31 \\
\hline $\begin{array}{l}\text { Transition from factor- } \\
\text { driven to efficiency-driven } \\
\text { stage }\end{array}$ & $+0,411$ & 0,128 & 15 \\
\hline Efficiency-driven stage & $\mathbf{+ 0 , 4 4 4}$ & 0,011 & 32 \\
\hline $\begin{array}{l}\text { Transition from efficiency- } \\
\text { driven stage to innovation- } \\
\text { driven stage }\end{array}$ & $\mathbf{+ 0 , 2 0 6}$ & 0,428 & 17 \\
\hline Innovation-driven stage & $\mathbf{+ 0 , 3 8 5}$ & 37 \\
\hline
\end{tabular}

Source: authors' own calculations using GI and GCI data

For the purpose of evaluating the refional competitiveness, this is useful to look on the correlation analysis results for EU and non-EU countries. The correlation results show that close interaction between globalization and competitiveness is more likely for non-EU countries, because their sample shows higher Spearman's correlation coefficient between GI and GCI (see Table 6).

Table 6. Correlation between ranks of GI and GCI taking into consideration countries' membership in the EU, Spearman's correlation coefficient, n-132 countries, 2015

\begin{tabular}{|c|c|c|c|}
\hline $\begin{array}{c}\text { Membership of a country } \\
\text { in the } \mathbf{E U}\end{array}$ & $\begin{array}{c}\text { Spearman's correlation } \\
\text { coefficient, } \mathbf{r}\end{array}$ & Statistical significance, $\boldsymbol{p} \mathbf{p}$ & Number of countries \\
\hline EU country & $\mathbf{+ 0 , 7 1 6}$ & 0,000 & 28 \\
\hline Non-EU country & $\mathbf{+ 0 , 7 6 7}$ & 0,000 & 104 \\
\hline
\end{tabular}

* Correlation is statistically significance if $\mathrm{p}<0,05$

Source: authors' own calculations using GI and GCI data

At the same time, results of partial correlation (based on the stage of development) between GI and GCI for EU and non-EU countries show that mutual intearction between globalization and competitiveness is more likely for EU countries (partial $r=+0,567$ ) than for non-EU countries (partial $r=+0,487$ ). (see Table 7)

Table 7. Partial correlation* between ranks of GI and GCI taking into consideration countries' membership in the EU, Spearman's correlation coefficient, n-132 countries, 2015

\begin{tabular}{|c|c|c|c|}
\hline $\begin{array}{c}\text { Membership of a country } \\
\text { in the EU }\end{array}$ & $\begin{array}{c}\text { Spearman's correlation } \\
\text { coefficient, } \mathrm{r}\end{array}$ & $\begin{array}{c}\text { Statistical significance, }{ }^{* *} \\
\mathrm{p}\end{array}$ & Number of countries \\
\hline EU country & $\mathbf{+ 0 , 5 6 7}$ & 0,000 & 26 \\
\hline Non-EU country & $\mathbf{+ 0 , 4 8 7}$ & 0,000 & 100 \\
\hline \multicolumn{3}{|c|}{$\begin{array}{c}* \text { Controlled variable }- \text { stage of development of a country } \\
* * \text { Correlation is statistically significance if } \mathrm{p}<0,05\end{array}$} \\
\hline
\end{tabular}

Source: authors' own calculations using GI and GCI data

On overall the results of correlation analysis indicated that the globalization level of a country and its competitiveness has strong positive statistically significant correlation, which is stronger for EU countries and countries on the efficiency-driven stage of development. It means that competitiveness under global economic 


\section{INSIGHTS INTO REGIONAL DEVELOPMENT}

ISSN 2669-0195 (online) http://jssidoi.org/jesi/

2019 Volume 1 Number 1 (March)

http://doi.org/10.9770/IRD.2019.1.1(3)

conditions is determined by the development stage of each region - competitiveness of a less developed region is more dependent on production factors, while competitiveness of a higher developed region is based on innovation.

\section{Conclusions}

The analysis of competitiveness concept leads to a conclusion that the competitiveness is a combination of institutions, policies and factors, which determine the productivity level of a territory, and are crucial for its economic development. The competitiveness involves a combination of elements of productivity, efficiency and profitability; the ability of a state (territory) to produce goods and services for export, successfully compete with other states (territories) in international markets, which promotes territorial growth and transition to the next stage of development; and the ability of state to manage, create and sustain a favourable environment for its people and enterprises, where people can improve their welfare and enterprises - increase their added value.

The impact of globalization on regional development depends on the development stage of a region in question regions, which are on the lower development stage and more dependent on the production factors are less competitive on a global scale, thus, the impact of globalization for them is greater. In turn, innovative regions, which are on a higher development stage are also more competitive globally and can easier withstand forces of globalization.

The regional competitiveness in the Factor driven stage is mainly based on so called basic factors - institutions; infrastructure; macroeconomic environment; health care and basic education. The regional competitiveness in the Efficiency driven stage is mainly based on the factors promoting efficiency - higher education and training; goods market efficiency; labour market efficiency; development of financial market; technological readiness; market size. Finally, the regional competitiveness in the Innovation driven stage is mainly based on the factors promoting innovation and specialised factors - business attractiveness; innovation.

Countries with higher level of globalization are more competitive and countries with higher level of competitiveness appear to be more globalized. The competitiveness under global economic conditions is determined by the development stage of each region - competitiveness of a less developed region is more dependent on production factors, while competitiveness of a higher developed region is based on innovation.

Taking into account various factors, which influence regions in a particular stage of development this is important for policy makers to decide, which policy instruments could be more efficient for increasing the regional competitiveness and, thus, also the level of development making them more competitive and less dependent on the impact of globalization.

\section{References}

Anderson, R. 1999. Attractive Cities. Stockholm: The Swedish council for building research.

Audretsch, D., Dohse, D. 2007. Location: A Neglected Determinant of Firm Growth. Review of World Economics, 143(1), 79-107.

Bhandari, A.K., Heshmati, A. 2005. Measurment of Globalization and Its Variations Among Countries, Regions and Over Time, Discussion Paper No.1578, the Institute for the Study of Labour (IZA) Discussion Series, April 2005, Bonn, Germany, p.4.

Capello, R., Caragliu, A., Nijkamp, P. 2009. Territorial Capital and Regional Growth: Increasing Returns in Cognitive Knowledge Use. Discussion Papers, No. 09-059/3. Tinbergen Institute. 


\section{INSIGHTS INTO REGIONAL DEVELOPMENT}

ISSN 2669-0195 (online) http://jssidoi.org/jesi/

2019 Volume 1 Number 1 (March)

http://doi.org/10.9770/IRD.2019.1.1(3)

Commision of the European Communities. 2005. Cities and the Lisbon Agenda: Assessing the Performance of Cities. Brussels: Directorate General Regional Policy. http://www.urbanaudit.org/Cities\%20and\%20the\%20lisbon\%20agenda.pdf

Commision of the European Communities. 2007. Growing Regions, Growing Europe. Fourth Report on Economic and Social Cohesion. Luxembourg: Office for Official Publications of the European Communities http://ec.europa.eu/regional_policy/sources/docoffic/official/reports/cohesion4/pdf/4cr_en.pdf

Commision of the European Communities. 2009. The Sixth Progress Report on Economic and Social Cohesion. Brussels: Commission of the European Communities. http://ec.europa.eu/regional policy/sources/docoffic/official/reports/interim6/com 2009295 en.pdf

Dunning J. 1993. Internationalizing Porter's diamond. Management International Review: special issue, 33(2), 47-62.

European Commission. 2017. The EU Regional Competitiveness Index 2016, Working Paper, Ed: Paola Annoni, Lewis Dijkstra, Nadia Gargano, 02/2017, Brussels.

European Commission. 2017. The EU Regional Competitiveness Index 2016, Working Paper, Ed: Paola Annoni, Lewis Dijkstra, Nadia Gargano, 02/2017, Brussels

European Commission. European Regional Competitiveness Index:

http://ec.europa.eu/regional_policy/en/information/maps/regional_competitiveness/

Florida, R. 2011. The Great Reset: How the Post-Crash Economy Will Change the Way We Live and Work. HarperBusiness, 2011. p. 240.

Garelli, S. 2002. Competitiveness of Nations: The Fundamentals.

http://members.shaw.ca/compilerpress1/Anno\%20Garelli\%20CN\%20Fundamentals.htm

Garelli, S. 2012. IMD World Competitiveness Yearbook 2012. Lausanne: IMD World Competitiveness Center.

Hernesniemi H., Lammi M., Yla-Anttila P. 1996. Advantage Finland - The Future of Finnish Industries: ETLA [the Research Institute of the Finnish Economy] report of the Finnish clusters' study. Helsinki: Taloustieto Oy.

IMD World Competitiveness Online: https://worldcompetitiveness.imd.org/

KOF Swiss Economic Institute: https://www.kof.ethz.ch/en/news-and-events/media/press-releases/2018/01/kof-globalisation-indexglobalisation-down-worldwide-in-2015.html

Lavrinenko, O., Ignatjeva, S., Ohotina, A., Rybalkin, O., Lazdans, D. 2019. The Role of Green Economy in Sustainable Development (Case Study: The EU States), Entrepreneurship and Sustainability Issues 6(3): 1013-1026. http://doi.org/10.9770/jesi.2019.6.3(4)

Lopez-Claros, A., Blanke, J., Drzeniek, M., Mia, I., Zahidi, S. 2006. Policies and institutions underpinning economic growth: Results from the competitiveness indexes. In: Lopez-Claros A. (Ed.) Global Competitiveness Report 2005-2006. Geneva: World Economic Forum, pp.16-34.

Mahbub ul Haq. 1991. Human Development Report 1991. United Nation Development Programme. New York: Oxford University Press. http://hdrnet.org/423/1/hdr_1991_en.pdf

Mill, J. S. 1859. On Liberty. Editor Gertrude Himmelfarb. UK: Penguin, 1985.

Pellegrini, G. 2006. Measures of competitiveness and attractiveness: a critical appraisal focused on Italy, Proceedings of the Scientific Meeting of the Italian Statistical Society, vol. 1, pp. 355-364. http://www.sis-statistica.it/files/pdf/atti/sessione\%20plenarie\%202006_355$\underline{\text { 364.pdf }}$

Pietrzak, M.B., Balcerzak, A. P., Gajdos, A., Arendt, Ł 2017. Entrepreneurial environment at regional level: the case of Polish path towards sustainable socio-economic development, Entrepreneurship and Sustainability Issues 5(2): 190-203. http://doi.org/10.9770/jesi.2017.5.2(2) 
INSIGHTS INTO REGIONAL DEVELOPMENT

ISSN 2669-0195 (online) http://jssidoi.org/jesi/

2019 Volume 1 Number 1 (March)

http://doi.org/10.9770/IRD.2019.1.1(3)

Porter M.E. 1998. On Competition. USA: Boston. 220.lpp.

Porter, M.E. 1990, The Competitive Advantage of Nations. New York: The Free Press.

Ricardo, D. 1817. On the Principles of Political Economy, and Taxation. 1st edition. Harmondsworth: Penguin reprint, 1971 (Hartwell, R. M. editor)

Sagiyeva, R,, Zhuparova, A., Ruzanov, R., Doszhan, R., Askerov, A. 2018. Intellectual input of development by knowledge-based economy: problems of measuring in countries with developing markets, Entrepreneurship and Sustainability Issues 6(2): 711-728. http://doi.org/10.9770/jesi.2018.6.2(17)

Sala-i-Martin X., Baller S., Crotti R., Di Battista A., Drzeniek Hanouz M., Geiger T., Gomez Gaviria D., Marti G. 2016. Competitiveness Agendas to Reignite Growth: Findings from the Global Competitive Index. In: Schwab K. (Ed.) The Global Competitiveness Report 20162017. Geneva: World Economic Forum, pp. 3-50.

Schwab K. 2017. The Global Competitiveness Report 2017-2018. Schwab, K (ed.), Geneva: World Economic Forum, p.41, 176-177, 320, 326

Schwab, K. 2015. The Global Competitiveness Report 2014-2015. Schwab, K (ed.), Geneva: World Economic Forum: p.4.

Schwab, K. 2016. The Global Competitiveness Report 2015-2016. Schwab, K (ed.), Geneva: World Economic Forum.

Serrano, A. 2003. City competitiveness and attractiveness: a new approach to evaluate economic development in Mexican cities. PhD Thesis, Department of Urban Studies, University of Glasgow.

Smith, A. 1776. Glasgow Edition of the Works and Correspondence Vol. 2a. An Inquiry Into the Nature and Causes of the Wealth of Nations, Vol. 1. http://files.libertyfund.org/files/220/0141-02_Bk.pdf

The World Economic Forum: https://www.weforum.org/

Экономическая библиотека [Econmics library]. 2011. Предмет и объект региональной экономики. http://ecolibrary.ru/1561

\section{Aknowledgements}

The research leading to these results has received funding from the European Union Seventh Framework Programme (FP7 2007-2013) under grant agreement No. 291823 Marie Curie FP7-PEOPLE-2011-COFUND
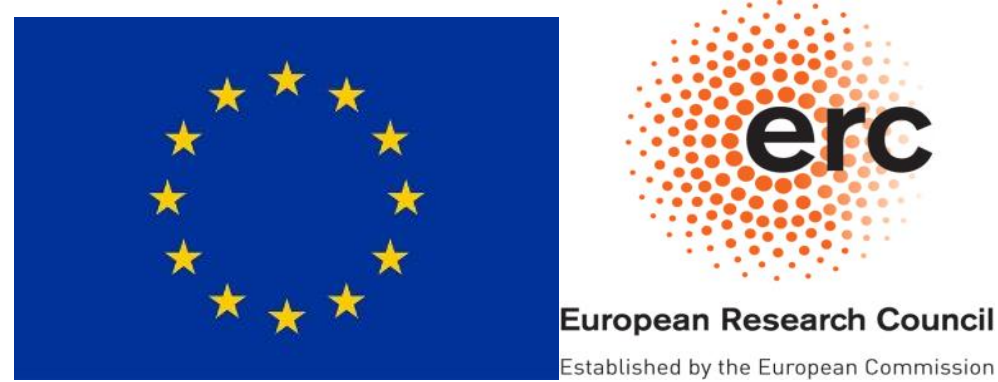
INSIGHTS INTO REGIONAL DEVELOPMENT

ISSN 2669-0195 (online) http://jssidoi.org/jesi/

2019 Volume 1 Number 1 (March)

http://doi.org/10.9770/IRD.2019.1.1(3)

Short biographical note about the contributors at the end of the article (name, surname, academic title and scientific degree, duties, research interests):

Zane ZEIBOTE PhD in Regional Economics, M.A. in Economic Policy Management, McGill University, Canada, Master degree in Economics from the University of Latvia. Since 2010 she is a Project Manager and lecturer at the University of Latvia. Her areas of expertise are EU economic integration, project management, regional and cohesion policy, economic and commercial diplomacy. She has been a project manager for Horizon-2020, Interreg, ERSAMUS+ and other projects. She has a long- standing experience in working in different capacities for the Ministry of Foreign Affair and working as an Advisor to the President of Latvia on Economic Affairs. Research interests: regional economics, regional policy, globalization, clusters, digital economy, international economic relations.

https://orcid.org/0000-0003-4571-6515

Tatjana VOLKOVA is a Professor of Strategic Management and Innovation Management at BA School of Business and Finance in Riga and a Member of Higher Education Council of Latvia, Steering Committee Member of Institutional Evaluation Program (IEP) of European University Association (Belgium) and Swiss Accreditation Council (Switzerland) member. She has been intensively involved in delivering accreditation and evaluation of HEI on behalf of different accreditation bodies nationally and internationally. Tatjana Volkova is a Latvia's Professors Board member and former Board member of Baltic Management Development Association, Head of Joint Professor's Council established by BA School of Business and Finance and Riga International School of Economics and Business Administration. The research interests are related to Competitiveness, Innovation management and Strategic foresight.

https://orcid.org/0000-0002-7599-8720

Kiril TODOROV, D.Sc. (Econ.) is Professor of Industrial Management and Entrepreneurship at the University of National and World Economy (UNWE) and Chairman of the Bulgarian Association for Management Development and Entrepreneurship (BAMDE). Kiril Todorov is the founder of university entrepreneurship education in Bulgaria and is Director of the Institute of Entrepreneurship at the UNWE. He is member of the Editorial Boards of International Review of Entrepreneurship (IRE), Quarterly Journal 'Economics and Organization of Enterprise', Poland, The International Journal of Management and Information Technology (IJMSIT), etc. He has publications with international authorities as David Smallbone, Friederike Welter, Alain Fayolle, and others. He was invited speaker in different international events on Management and Entrepreneurship in USA, Denmark, Brazil, UK, Turkey, Slovenia, Romania, Kazakhstan, Brunei. He is also Chairman of the well-known BAMDE Conference on Entrepreneurship.

https://orcid.org/0000-0002-3508-7914

Copyright (C) 2019 by author(s) and VsI Entrepreneurship and Sustainability Center

This work is licensed under the Creative Commons Attribution International License (CC BY).

http://creativecommons.org/licenses/by/4.0/

(c) (i) Open Access 